\title{
Flood discharge analysis of Brang Ode River as a disaster mitigation effort in Kalimango Village
}

\author{
Imam Solihin Al-Abbas ${ }^{1}$, Eko Pradjoko ${ }^{1 *}$, and Heri Sulistiyono ${ }^{1}$ \\ ${ }^{1}$ University of Mataram, Faculty of Engineering, Study Center of Disaster Risk Management, 83115 Mataram, Indonesia
}

\begin{abstract}
Flood is a hydrometeorological disaster that often occurs in West Nusa Tenggara, especially in the Brang Ode River, Kalimango Village, Alas District, Sumbawa Regency. One of the worst floods ever happened was on December $12^{\text {th }}$, 2016, which caused several villages to be inundated and houses along the river to wash away. This study aims to obtain the peak discharge from the worst flood that has ever occurred. This model is simulated using HEC-RAS 5.0.7 and QGIS for mapping the flood inundation area. Terrain data used DEMNAS. The peak discharge is obtained from the modeling results based on the flood inundation area, validated with the flood map from the DESTANA (disaster resilient village) Community of Kalimango Village. The modeling results showed that the peak flood discharge is $950 \mathrm{~m} 3 / \mathrm{s}$, with the inundation area $150,752.07 \mathrm{~m} 2$. The actual peak flood discharge can be smaller or larger than the modeling results. It may be affected by the DEMNAS raster data accuracy.
\end{abstract}

\section{Introduction}

Indonesia is a country that is very prone to natural disasters. A flood is an annual natural disaster that often occurs. This hydrometeorological disaster is common throughout Indonesia. Nevertheless, until now, there are still no practical steps to deal with this problem.

The heavy rain that occurred on December 12th, 2016, caused the Brang Ode River to overflow. The flood caused at least three villages to be inundated, and several houses along the river washed away. Floods caused damage to several houses and agricultural areas. In addition, floods also caused damage to the community's economy due to damage to agricultural land, access roads, and bridges.

In HEC-RAS, rivers can be modeled in one and two dimensions. One-dimensional modeling calculates water flow through a predetermined path from upstream to downstream, with the flow velocity only changing or differing in one axis direction. In two-dimensional modeling, water flow can flow in two axis directions with a changing or different flow velocity. Two-dimensional models are suitable for modeling floodwaters [1].

In dealing with disasters, especially floods, the community needs to know the risks they will face in the area where they live. Such as knowledge in disaster control which emphasizes risk reduction (mitigation). The community is the first party to deal with disaster risk so that mitigation is more effective with the active participation of the community. For this reason, a flood hazard map that can be integrated as a recommendation in spatial planning based on disaster mitigation is needed [2].

The solution is needed to see how the flood occurred and the area to be submerged based on the existing discharge. So one way of flood disaster mitigation efforts is to do the Flood Discharge Analysis of Brang Ode River as a Disaster Mitigation Effort in Kalimango Village, Alas District, Sumbawa Regency. The objective is to see the characteristics of the floods that occurred in Kalimango Village. The modeling can help the community in reducing and minimizing the impact of the flood disaster.

\section{Study areas}

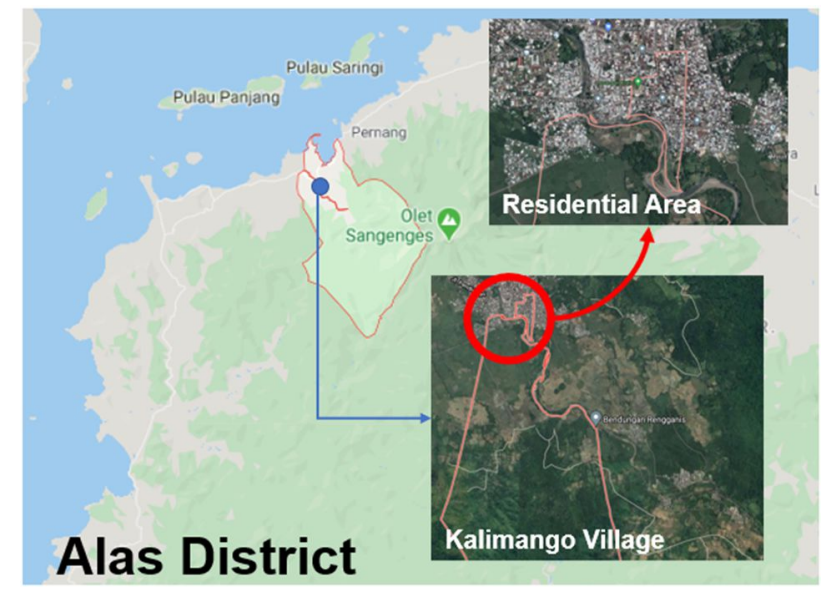

Fig. 1. Study area.

* Corresponding author: ekopradjoko@unram.ac.id 
We researched in the Kalimango Village, Alas District, Sumbawa Regency. The Dalam Village bordered on the north side, the Baru Village on the west, the Marenteh Village on the south, and the Juranalas Village on the east. The Kalimango village is within the Dalap watershed coverage. This watershed is the leading supplier for the Brang Ode River and has two weirs, namely the Marente Weir and the Rengganis Weir. The Dalap watershed has an area of $97.22 \mathrm{~km}^{2}$ and is in the category of small rivers. More details can be seen in Fig 1 below.

In the last few months during the 2020-2021 rainy season, the capacity of the Brang Ode River could still accommodate the large river water discharge caused by light to moderate rain. Based on the BMKG weather early warning report, there was light to moderate rain in the Alas District and surrounding areas on January 17-18, 2021.

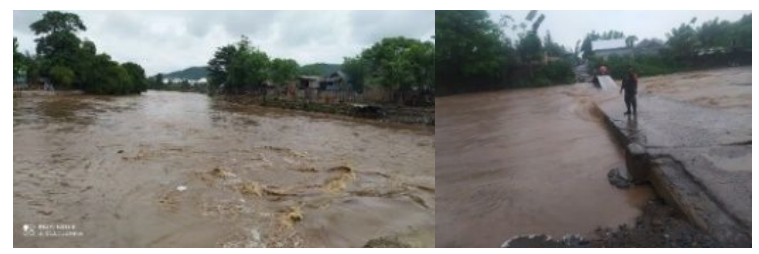

Fig. 2. Brang Ode River in Cinta Bridge after rain on January 17-18, 2021.

There was an increase in the water level in the Brang Ode River during the first rain, but the river's capacity could still accommodate it. Meanwhile, during the second rain, there was a significant rise in water level. Fig 2 shows that the water level of the Brang Ode River rises until it reaches the Cinta Bridge floor slab.

\section{Methodology}

The data used in this study are main data and supporting data, namely data of first and second parties. The first data were obtained from interviews with local communities and observations in Kalimango Village. The second data is obtained from the relevant agencies authorized to produce the data for specific purposes. Secondary data includes DEM data obtained from the official website of the Indonesian Geospatial Information Agency and several other supporting data for the Dalap watershed area from related agencies/parties.

Data analysis was performed using HEC-RAS version 5.0.7. with input data in the form of terrain data, flow discharge, boundary conditions, river parameters, and set parameters for running the model [3]. The inundation map was then analyzed using the QGIS 3.10.

\subsection{Validation map}

Due to the absence of detailed records of floods that occurred in Kalimango Village, in the activity "Capacity Strengthening Program of Kalimango Village for Flood Risk Reduction," the action has been made a flood risk map of Kalimango Village. The map contains the area of flood inundation that occurred on December 12th, 2016, in Kalimango Village. The flood inundation area on the map is based on information from residents and is supported by media coverage and direct field observations. The flood inundation map can be seen in Fig 3 below.

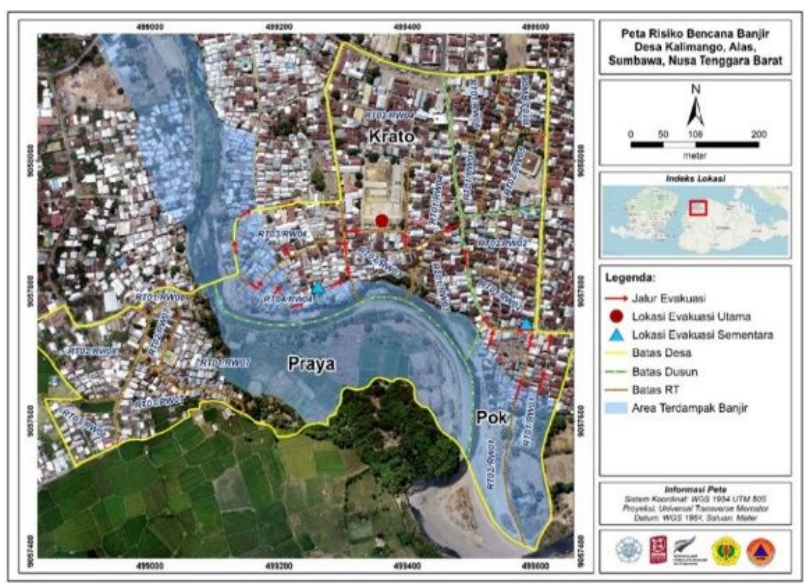

Fig. 3. Flood inundation map of Brang Ode River.

Based on the flood inundation map in Fig 3, it was found that the area of the Brang Ode River inundation in Kalimango Village is $134,468.40 \mathrm{~m}^{2}$. The map only contains inundation that occurs in residential areas. Furthermore, the inundation area is used as a reference to validating the simulated flood inundation model. In the analysis and validation of the inundation model, the upstream inundation boundary is used as a reference for the onset of flooding in Kalimango Village. The village administrative boundary becomes the reference for the downstream inundation limit, as shown in Fig 4. The flooded overflow that occurs on the left and right banks of the river is something that will be analyzed.

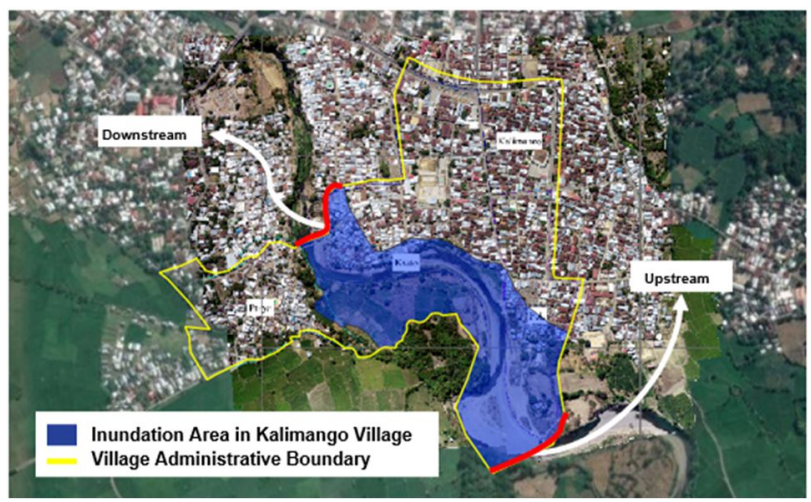

Fig. 4. Validation map.

\subsection{Manning's roughness coefficient}

The manning's value of the 2D modeling area is divided into 2, namely the $n$ value for the channel and the flood plains. Because the flood plain consists of agricultural land and densely populated settlements, the value of $n$ for the flood plain is also divided into 2. So the modeling used three values of $n$. The Manning's coefficient for each landuse classification can be seen in table 1 [4]. 
Table 1. Manning's roughness coefficients.

\begin{tabular}{|c|c|}
\hline Land Use Type & $\begin{array}{c}\text { Manning's } \\
\text { n value }\end{array}$ \\
\hline Water area & 0.025 \\
\hline Farmland & 0.04 \\
\hline Forest & 0.16 \\
\hline Factory site & 0.05 \\
\hline Residential area (low density) & 0.05 \\
\hline Residential area (high density) & 0.15 \\
\hline Road, vacant land & 0.025 \\
\hline
\end{tabular}

Manning's standard values for river channels obtained from kind of literature ranged from 0.03-0.04. Because there are several vegetations with different amounts of variation, it is determined that the value of the manning's roughness coefficient for the Brang Ode River is 0.05. The determination of Manning's roughness coefficient for the residential areas flood plains is based on Table 2, which is 0.1 . As for agricultural land, manning's coefficient ranges from $0.035-0.04$. In this case, 0.04 is used for agricultural land in Kalimango Village.

\subsection{Riverbed slope}

The calculation and measurement of the riverbed slope are based on changes in the slope along the river channel. Because there are several changes in certain parts of the channel slope, the river slope segment is divided based on each slope change. In this study, the slope of the riverbed channel is divided into four segments. Segment division starts from downstream to upstream.

Table 2. Bed slope of Brang Ode River.

\begin{tabular}{|c|c|c|c|}
\hline Segments & $\begin{array}{c}\text { Horizontal } \\
\text { distance, } \\
\text { H (m) }\end{array}$ & $\begin{array}{c}\text { Elevation } \\
\text { difference, } \\
\text { V (m) }\end{array}$ & $\begin{array}{c}\text { River slope, } \\
\mathbf{S}_{\mathbf{~}}\end{array}$ \\
\hline Segment 1 & 1088.10 & 2.8570 & 0.00263 \\
\hline Segment 2 & 2881.91 & 11.049 & 0.00383 \\
\hline Segment 3 & 1862.33 & 12.502 & 0.00671 \\
\hline Segment 4 & 1267.76 & 30.295 & 0.02390 \\
\hline \multicolumn{4}{|c|}{ Average } \\
\hline
\end{tabular}

From Table 2, it can be seen that the change in the slope of the river channel bed in segment 1 to segment 3 is not very significant. The average slope value of the bottom river channel is 0.00439 . There is a significant change in the riverbed slope in the upstream area of the Brang Ode River, with a riverbed slope of 0.0239 . The significant difference in slope changes is caused by the insufficient DEM data in the upstream part of the river. Based on this, the bottom slope value of the Brang Ode River channel is used, which is 0.0043 . Since it is considered that the upstream channel is slightly steeper than the previous section, a more significant average river bed slope is used. In this study, the Brang Ode River channel bed slope of 0.005 is applied.

\subsection{Terrain data}

It takes at least two digital elevation model data to form a Brang Ode River. The digital elevation model data is combined in a mosaic (virtual build raster) way using QGIS 3.14. Once combined, the digital elevation model is clipped to the required area with the clip raster command. The clipped data is then used as material to create river geometry in HEC-RAS 5.0.7.

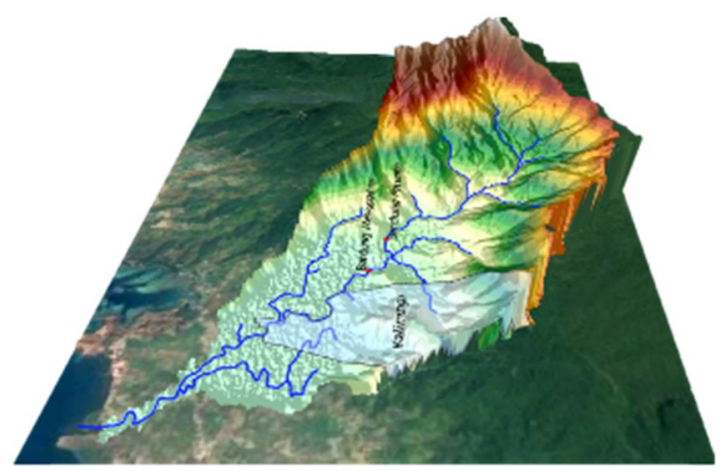

Fig. 5. Digital elevation model of Dalap Watershed

The digital elevation model data from Geospatial Information Agency is the most accurate spatial data available. The size $8 \mathrm{~m} \times 8 \mathrm{~m}$ is quite good compared to the $30 \mathrm{~m} \times 30 \mathrm{~m}$ digital elevation from the SRTM data. However, because DEMNAS is data from several data sources and the conversion of datums, it results in anomalies in the shape of the terrain. Such as an area that is higher or lower than the shape of the surface should be. Other landform anomalies are also seen in flow patterns and river estuaries.

\subsection{Flow data (Discharge)}

Given the notation Q, river flow discharge is the amount of water flowing through the cross-section of the river per unit time, which is usually expressed in cubic meters per second [5]. The discharge at a location in the river can be estimated in the following way:

- Measurement in the field (at the specified location).

- Based on discharge data from nearby stations.

- Based on rain data.

Because there is no recorded discharge data, observations and interviews with communities around flooded areas are the primary data that will be processed into flood discharge data. The data was obtained from the results of public information on the flooding that occurred. Furthermore, a simple hydrological analysis 
was carried out to obtain design flood discharge data by the actual flood event. The hypothetic discharge is entered to produce the inundation area as in the validation map. Discharges with similar inundation will then be analyzed.

Interviews were conducted with the community regarding the worst flooding that has occurred in recent years. It was found that the duration of the rain that occurred was for more than 2 hours. Since the first rain fell, it takes for flooding in Marente Weir is 1-2 hours. Moreover, according to information from the community, the estimated travel time for flooding from Marente Wier to Kalimango Village is about 30 minutes.

\section{Results and discussion}

Based on the Kalimango Village Flood Inundation map, the flood inundation area results after 2D flow modeling using HEC-RAS software. The flood inundation area generated by each discharge is then validated using the inundation area based on the "Flood Risk Map of Kalimango Village, Alas, Sumbawa, West Nusa Tenggara" in Fig 4. Three scenarios of peak discharge are used for analysis. Each of these discharges produces a different flood inundation area. After being analyzed, one scenario of peak flood discharge was selected, which resulted in the flood inundation area according to the validation map.

Based on the interview results, it was found that the length of time required by the flood from starting to rain until it reached the Marente Weir is about 1.5 hours. The flood travel time to reach Kalimango Village is about 30 minutes. There is a lot of mud content when a flood occurs. An inundation depth is about $0.5 \mathrm{~m}$ on the banks around the Cinta bridge.

\subsection{Inundation area of scenario 1}

This scenario is conducted by using a discharge amount of $800 \mathrm{~m}^{3} / \mathrm{s}$. A stable computational interval of 1 second is used for running the simulation and mapping out every 1 minute. The simulation does not start with an empty river condition; the hot start is used with a base flow rate of $10 \mathrm{~m}^{3} / \mathrm{s}$. The flood inundation simulation results can be seen in Fig 6.

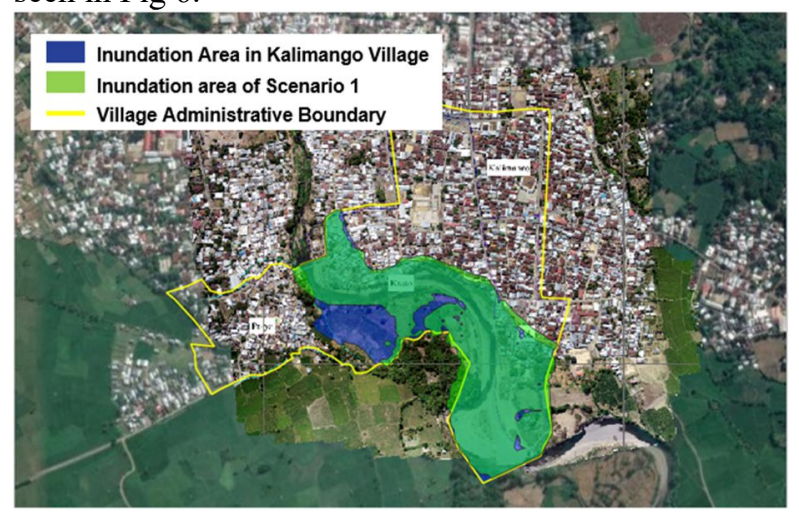

Fig. 6. Flood inundation area of scenario 1.

From the simulation results, the flood inundation in the residential area of Kalimango Village is 141,251.74 $\mathrm{m}^{2}$. There is a leak on the right bank of the flood; if the flood area reduces it in the leak, the actual flood inundation area for scenario 1 is $122,971.59 \mathrm{~m}^{2}$. The area is smaller than the actual flood inundation area. As shown in Fig 6, the flood inundation area of Kalimango Village is larger than the flood inundation with scenario one discharge. The flood inundation in Kalimango Village is depicted by blue polygons, while inundation with scenario one discharge is green polygons.

The average velocity of flood flow in a residential area is about $2.8 \mathrm{~m} / \mathrm{s}$. The flood travel time required from Marente Weir to reach the Kalimango Village residential area is 38 minutes. The floodwater level varies depending on the elevation of the plain and the depth of the river. At the Cinta Bridge point, the flood water level is $9.67 \mathrm{~m}$, with the flood bank elevation as high as $9.4 \mathrm{~m}$. The flood inundation of the Cinta Bridge floodplain is $0.27 \mathrm{~m}$.

\subsection{Inundation area of scenario 2}

This scenario is conducted by using a discharge amount of $950 \mathrm{~m}^{3} / \mathrm{s}$. A stable computational interval of 1 second is used for running the simulation, and the mapping out interval is every 1 minute. The simulation does not start with an empty river condition; the hot start is used with a base flow rate of $10 \mathrm{~m}^{3} / \mathrm{s}$. Flood inundation simulation results can be seen in Fig 7 .

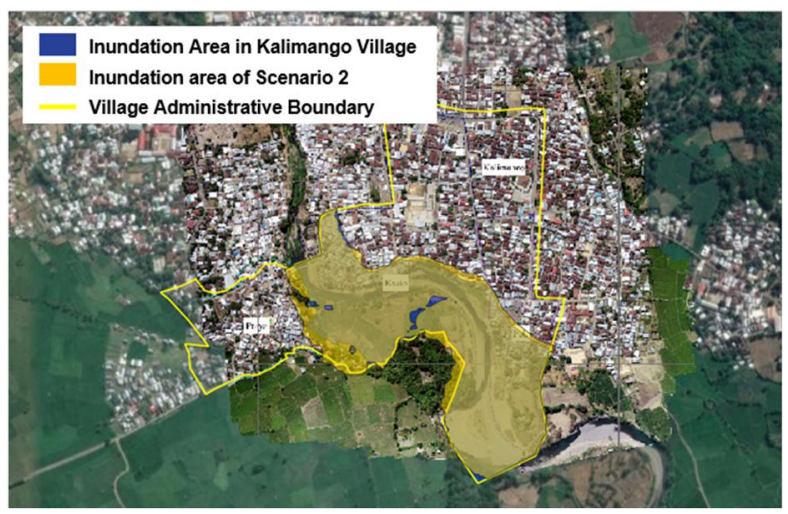

Fig. 7. Flood inundation area of scenario 2

From the simulation results, the flood inundation area in the residential area of Kalimango Village is 170.659.10 $\mathrm{m}^{2}$. There is a leak on the right bank of the flood; if the inundation area reduces it on the leak, the actual flood inundation area for scenario 2 is $150,752.07 \mathrm{~m}^{2}$. This area is slightly larger than the actual flood inundation area, as shown in Fig 7. The flood inundation in Kalimango Village is depicted by a blue polygon, while a yellow polygon represents the flood inundation in scenario 2 .

The average velocity of flood flow in a residential area is $\pm 3.2 \mathrm{~m} / \mathrm{s}$. The flood travel time required from Marente Weir to reach the residential area of Kalimango Village is 32 minutes. The floodwater level varies depending on the elevation of the plain and the depth of the river. At the Cinta Bridge point, the floodwater level is $9.9 \mathrm{~m}$, with the flood bank elevation as high as $9.4 \mathrm{~m}$. The flood inundation of the Cinta Bridge floodplain is $0.5 \mathrm{~m}$. 


\subsection{Inundation area of scenario 3}

This scenario is conducted by using a discharge amount of $1,100 \mathrm{~m}^{3} / \mathrm{s}$. A stable computational interval of 1 second is used to run the simulation and map out every 1 minute. The simulation does not start with an empty river condition; the hot start is used with a base flow rate of 10 $\mathrm{m}^{3} / \mathrm{s}$. The simulated flood inundation can be seen in Fig 8 .

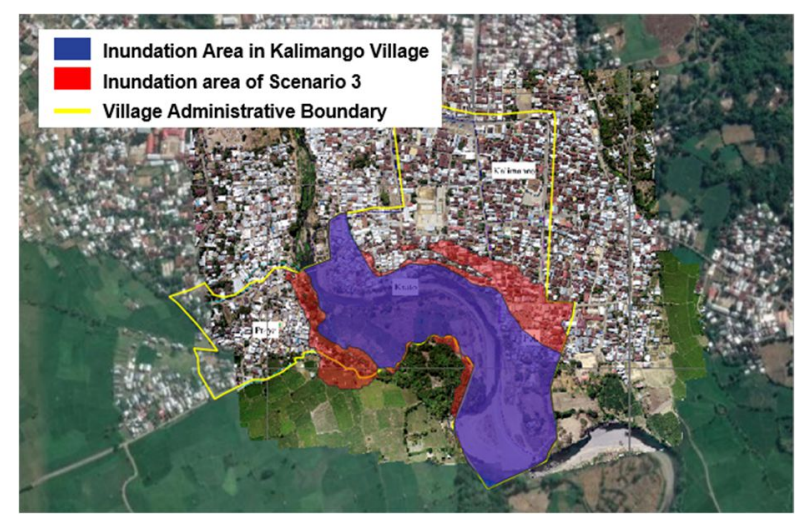

Fig. 8. Flood inundation area of scenario 3

From the simulation results, the flood inundation area in the residential area of Kalimango Village is 182,184.98 $\mathrm{m}^{2}$. The inundation area is larger than the flood inundation area of Kalimango Village, as shown in Fig 8. In this amount of discharge, flood inundation also includes inundation on the leakage of the right bank of the river. Flood inundation in Kalimango Village is depicted with blue polygons, while flood inundation with discharge scenario three is depicted with red polygons.

The average velocity of flood flow in a residential area is $\pm 3.45 \mathrm{~m} / \mathrm{s}$. The flood travel time required from Marente Weir to reach the residential area of Kalimango Village is 28 minutes. The floodwater level varies depending on the elevation of the plain and the depth of the river. At the Cinta Bridge point, the floodwater level is $10.4 \mathrm{~m}$, with the flood bank elevation as high as $9.4 \mathrm{~m}$. The flood inundation in the Cinta Bridge floodplain point is $1 \mathrm{~m}$.

\subsection{Inundation validation}

From the modeling (simulation) and analysis results, it was found that the error percentage value of the validation inundation area with the modeling results was $8.55 \%$ for scenario 1, $12.11 \%$ for scenario 2 , and $35.49 \%$ for scenario 3 . The percentage error of the inundation area in scenario 1 was close to the inundation area validation, but the resulting inundation pattern is smaller and different. For scenario 2, the percentage of inundation area error generated is slightly larger than that of the validation map inundation. However, overall, the resulting inundation pattern is similar to the validation inundation map. While in scenario 3, the percentage of error and the resulting inundation area is quite large, with a different inundation pattern from the inundation of the validation map. Based on this, scenario two was chosen as the peak discharge of the Brang Ode River in Kalimango Village.

The magnitude of the error percentage value in scenario two is caused by the poor condition of the field data used. The percentage of the inundation area error can be reduced when using fairly detailed terrain data with a small grid accuracy. The better the accuracy of the field data used, the smaller the percentage of error generated. The excellent condition of the data makes the modeled inundation area close to or even equal to the original inundation area (validation inundation).

\section{Conclusions}

Based on the interview results, it was found that the length of time it took for the flood from starting to rain until it reached the Marente Weir was 1.5 hours. After modeling and analysis, it was found that the appropriate flood model for the Brang Ode River in Kalimango Village is scenario 2. The travel time for flooding to reach Kalimango village is 32 minutes. The velocity of flood flow in residential areas is $3.2 \mathrm{~m} / \mathrm{s}$ with a peak discharge of $950 \mathrm{~m}^{3} / \mathrm{s}$. So the total time required by flooding from the start of rain to flooding in Kalimango Village is 2 Hours 2 Minutes. The actual flood discharge may be larger or smaller than the modeling results. The accuracy of the DEM data influences this and also the value of the river parameters used. It is hoped that further research can develop using a good DEM and appropriate river parameters to get model results close to the actual event.

\section{References}

1. G. W. Brunner, HEC-RAS River Analysis Sistem: Hydraulic Reference Manual, US Army Corps of Engineers, Institute for Water Resources, Hydrologic Engineering Center, Davis, CA, USA (2016)

2. W. Budiarti, E. Gravitiani, Mujiyo, JTL, 18, 242 (2017)

3. G. W. Brunner, CEIWR-HEC, HEC-RAS River Analysis System, 2D Modeling User's Manual Version 5.0. US Army Corps of Engineers, Institute for Water Resources, Hydrologic Engineering Center, Davis, CA, USA (2016)

4. A. Ryosuke, T. Ishikawa, T. Kojima, M. Tomaru, S. Maeno, Nat. Hazards Earth Syst. Sci., 17, 1876 (2017)

5. B. Triajmodjo, Applied Hydrology, September, Yogyakarta, Indonesia (2010). 